\title{
THE EFFECT OF IRRIGATION FREQUENCY AND RATE UNDER TRICKLE IRRIGATION MANAGEMENT ON YIELD GREEN BEAN GROWN IN CLAY LOAM SOIL
}

\author{
S.M. Hafez*; M.M. Shaheen**; M. S. Abuarab***
}

\begin{abstract}
This study was conducted over 2 years (2013 and 2014) to establish the optimal combinations between irrigation frequency and rate for trickleirrigated green bean using water production functions and water useyield relationships. A field experiment was conducted using a randomized complete block design with three irrigation frequencies $\left(F_{1}, F_{2}\right.$ and $F_{3}$, irrigation events once every 1,2 and 3 days, respectively) and three trickle irrigation rates $\left(I_{1}: 1.00, I_{2}: 0.80\right.$, and $I_{3}: 0.60$ of the estimated evapotranspiration, ET). Our results show that yield variables and water use efficiencies (WUEs) increased with increasing irrigation frequency and rate, with non-significant differences between $F_{1}$ and $F_{2}$ in yield variables and between $I_{1}$ and $I_{2}$ in WUEs. Moreover, the combination between various irrigation frequencies and rates had an important effect on yield variables and WUEs, with the highest values being found with $F_{1} I_{2}$ and $F_{2} I_{1}$ and the lowest for $F_{2} I_{3}$ and $F_{3} I_{3}$. The $F_{1} I_{3}$ treatment had grain yield and yield components values similar to those obtained for the $F_{2} I_{3}$ treatments and WUEs values similar to those obtained for the $F_{2} I_{3}$ and $F_{3} I_{1}$ treatments. Production functions of yield versus seasonal crop ET were linear for all combinations of irrigation frequency and rate and for all irrigation frequency treatments with the exception of the $F_{1}$ treatment, which instead showed a second order relationship. In conclusion, we identified the optimal coupling combinations between irrigation frequency and water application rate to achieve the maximum yield and WUEs.
\end{abstract}

\footnotetext{
*B.SC. of Agriculture Eng. - Faculty of Agric. - Cairo Univ.

${ }^{* *}$ Professor of Vegetable - Faculty of Agric. - Cairo Univ.

****Associate Professor of Agriculture Eng. - Faculty of Agric. - Cairo Univ.
} 


\section{INTRODUCTION}

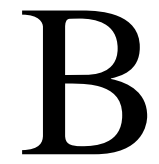

y the year 2050, it is forecast that there will be an annual global water shortage of 640 billion cubic meters (Spears, 2003).Given that water shortages currently plague almost every country in North Africa and the Middle East, insufficient water supply for irrigation in these regions, even in the short term, will almost certainly become the norm rather than the exception. Therefore, water shortage events have gained increasing importance in both the scientific and political agendas. Because the irrigation sector is the largest consumptive user of water, accounting for $71 \%$ of the fresh water use across the world, it is necessary for irrigation management practices to shift from emphasizing production per unit area towards maximizing the production per unit of irrigation water consumed (Fereres and Soriano, 2007).

Deficit evapotranspiration is also among the techniques of increasing effective use of water. Deficit evapotranspiration can be used either through agronomic practices or through changing management schemes to decrease crop evapotranspiration $\mathrm{ET}_{\mathrm{C}}$. Crops are exposed to water stress either throughout the entire growth season or at certain growth stages. It is therefore possible to save irrigation water without significant yield decrease which implies that irrigated area can be increased without additional water supply available (Merriam, 1965).

The main approach in deficit irrigation practice is to increase crop water use efficiency by eliminating those irrigations with the least impact on crop yield. In the areas where water supplies are limited and unit water costs are expensive, the best irrigation practice is not necessarily that which gives the highest yield. (English,1990).

Pulsing irrigation refers to the practice of irrigating for a short period then waiting for another short period, and repeating this on-off cycle until the entire irrigation water is applied (Eric et al., 2004). High-frequency water management by trickle irrigation minimizes soil as a storage reservoir for water, provides at least the daily requirements of water to a portion of the root zone of each plant, and maintains a high soil matric potential in the 
rhizosphere to reduce plant water stress (Phene and Sanders, 1976; Nakayama and Bucks, 1986).

WUE can be optimized by the adoption of irrigation frequency practices (Costa et al., 2007). To this regard, drip irrigation has contributed to improve WUE by significantly reducing runoff and crop evapotranspiration $\left(\mathrm{ET}_{\mathrm{c}}\right.$ ) losses (Stanghellini, et al., 2003; Jones, 2004; Kirnak and Demirtas, 2006).

The goal of deficit irrigation is to increase crop water use efficiency (WUE) by reducing the amount of water applied with watering or by reducing the number of irrigation events (Kirda, 2002). Deficit irrigation involves the use of appropriate irrigation schedules, which mostly derive from field trials (Oweis and Hachum, 2001), and this because crop sensitivity to water deficit during growing season changes with the phonological stage (Istanbulluoglu, 2009). Moreover, studies have shown that water deficit during certain stages of growing season improves fruit quality, although water limitations may also determine fruit yield losses (Patanè and Cosentino, 2010).

The objectives of this study are to: (i) evaluate the impacts of trickle irrigation frequency and deficit irrigation on green bean production and water use efficiency (WUE). (ii) determine the optimum coupling combinations between irrigation frequency and water application rate, to seek maximum yield and WUE simultaneously for trickle irrigated green bean using water production functions and water use-yield relationships. (iii). studding effects of irrigation frequency and deficit irrigation on the root dynamics of green bean plants, cultivated under arid conditions.

\section{MATERIALS AND METHODS}

\subsection{Open-field experiment}

Field experiments were conducted during the years 2012-20113 and 2013-2014, at El-Ayat El-Giza governorate, Egypt (latitude 30.1113N, longitude $31.4138 \mathrm{E}$, and mean altitude $74 \mathrm{~m}$ above sea level). The soil of the experimental site is classified as clay loam. Some physical and chemical properties of the experimental soil are given in Table 1. 
Irrigation water has been obtained from a deep well located in the experimental area, with $\mathrm{pH} 7.43$, and an average electrical conductivity of $0.59 \mathrm{dS} \mathrm{m}^{-1}$.

Table1. Some physical and chemical properties of the experimental soil

\begin{tabular}{cccccc}
\hline $\begin{array}{c}\text { Soil depth } \\
(\mathrm{cm})\end{array}$ & Texture & $\begin{array}{c}\text { Field } \\
\text { capacity } \\
(\%)\end{array}$ & $\begin{array}{c}\text { Wilting } \\
\text { point } \\
(\%)\end{array}$ & $\begin{array}{c}\text { Bulk density } \\
\left(\mathrm{g} \mathrm{cm}^{-3}\right)\end{array}$ & $\mathrm{pH}$ \\
\hline $0-20$ & Clay loam & 43.4 & 22.3 & 1.30 & 7.92 \\
$20-40$ & Clay loam & 43.6 & 22.5 & 1.30 & 7.88 \\
$40-60$ & Clay loam & 44.0 & 23.7 & 1.29 & 7.89 \\
\hline
\end{tabular}

\subsection{Experimental design, treatments and agronomic practices}

A randomized complete block design with three replicates was used in each season. Different treatments of irrigation frequency and water application rate were randomly assigned. A layout of the experimental plots is shown in Fig. 1.The trickle irrigation system was divided into three main sectors, with the irrigation frequency treatments (once every 1 , 2 and 3days) being assigned to the three sectors. The water application rate treatments $\left(\mathrm{I}_{1}: 1.00 \mathrm{ET}_{\mathrm{c}}, \mathrm{I}_{2}: 0.80\right.$ and $\mathrm{I}_{3}: 0.60$ of the estimated crop evapotranspiration) were randomly nested within each main sector as a subplot, with each subplot having three replicates of the same water application rate. Each subplot had one valve and one flow meter to control water application and measure the irrigation quantity, respectively. The amount of irrigation water applied, I, was determined from the calculated water requirement for green bean $(\mathrm{mm})$ as determined from the basal crop coefficient $\left(\mathrm{K}_{\mathrm{cb}}\right)$, and one for soil evaporation $\left(\mathrm{K}_{\mathrm{e}}\right)$ and the daily reference evapotranspiration $\left(\mathrm{ET}_{\mathrm{o}}\right)$ using the following equation:

$\mathrm{I}=\mathrm{ET}_{\mathrm{o}}\left(\mathrm{K}_{\mathrm{cb}}+\mathrm{K}_{\mathrm{e}}\right)$

$\mathrm{ET}_{\mathrm{o}}$ was calculated by the Penman-Monteith method (Allen et al., 1998) using daily data from a meteorological station located within $500 \mathrm{~m}$ of the research site. 


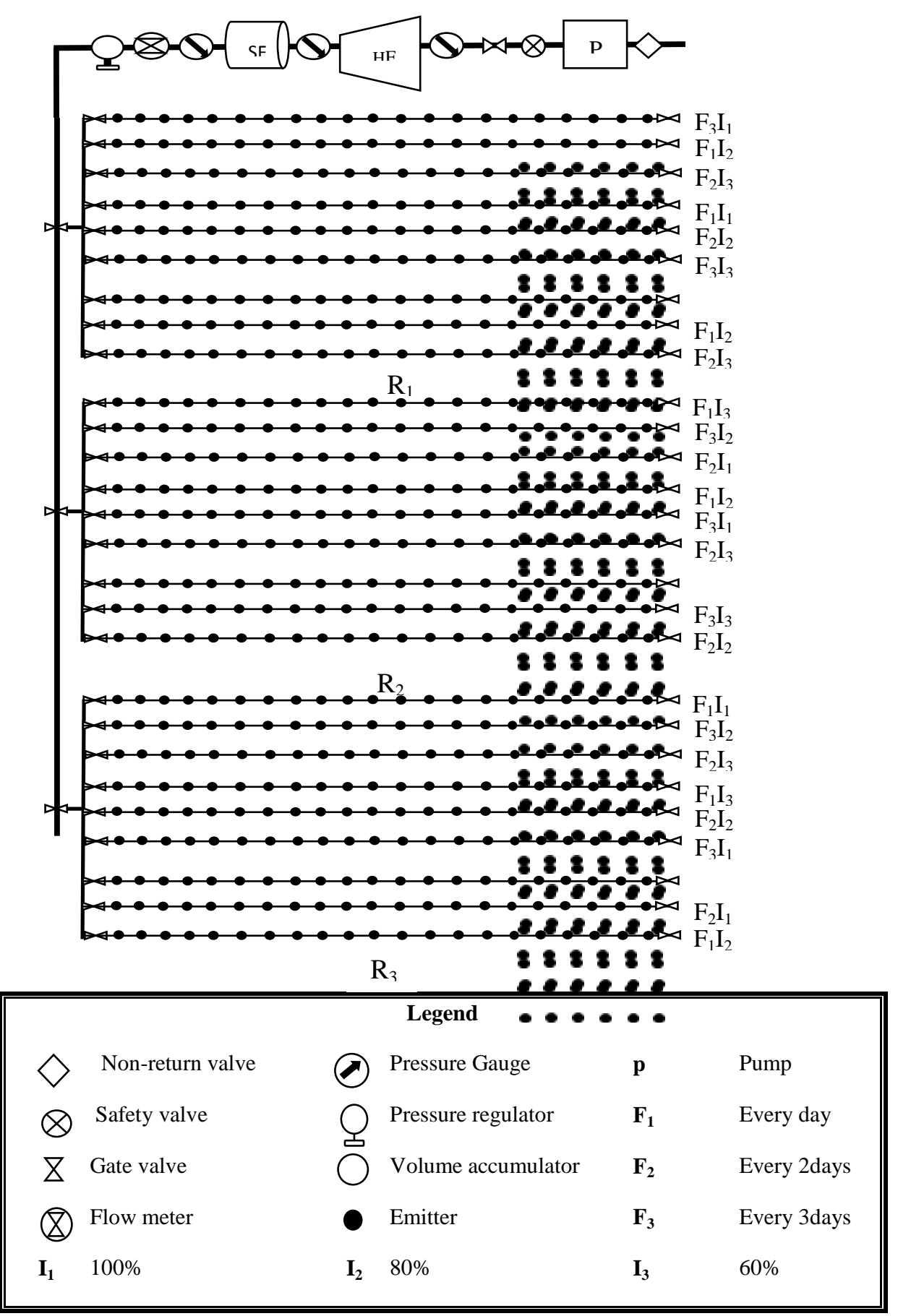

Fig. 1. Layout of an experimental design that includes three irrigation frequencies and three irrigation rates. 
Each $21 \mathrm{~m}^{2}$ subplot consisted of three polyethylene lateral drip lines (16 $\mathrm{mm}$ in diameter, and 0.3memitter spacing, Euro drip Greece) with a length of $10 \mathrm{~m}$. The lateral line was laid out along each green bean row at $0.7 \mathrm{~m}$. The Hydraulic characteristics experiments were carried out the National Irrigation Laboratory of Agricultural Engineering Research Institute (AERI), Dokki, Giza emitters had a operating pressure of 0.13 MPa. The water application uniformity was calculated from the statistical distribution of emitter flow rates in terms of coefficient of variation $(v)$ and emission uniformity (EU) using equations (2) and (3) (Keller and Karmeli, 1975), as follows:

$$
\begin{aligned}
& v=\frac{s d}{q_{a}} \\
& E U=100\left(1.0-1.27 \frac{v}{\sqrt{N_{p}^{\prime}}}\right) \frac{q_{n}}{q_{a}}
\end{aligned}
$$

Where: $\mathrm{s}$ is the standard deviation of drippers discharge (lph); $\mathrm{q}$ the mean dripper flow rate (lph) (Table 4$), v$ manufacturer coefficient of variation, $\mathrm{N}_{\mathrm{P}}$ the number of emitters per plant, $\mathrm{q}_{\mathrm{n}}$ is the minimum discharge rate $(1 / \mathrm{h}), \mathrm{q}_{\mathrm{a}}$ The average flow rate of all emitters $(\mathrm{lph})$. 2.3. Crop evapotranspiration measurements and irrigation water compensation

Three seeds (Polista) were sown around each emitter on 12 October 2013 and 12 October 2014 to obtain a final plant population of about 90,000 plants $\mathrm{ha}^{-1}$. Nitrogen fertilizer was applied at a rate of $50 \mathrm{~kg} \mathrm{ha}^{-1}$ of $\mathrm{N}$ as ammonium sulphate $(20.5 \%)$ by fertigation. Nitrogen fertilizer was added 2 weeks after sowing in six equal weekly doses $\mathrm{P}_{2} \mathrm{O}_{5}$ fertilizer was applied at a level of $20 \mathrm{~kg}$ ha-1 of $\mathrm{P}$ as calcium super phosphate. Whole of phosphorus was applied basally before sowing in all treatments. Potassium fertilizer was applied 5 weeks after sowing at a level of $41.5 \mathrm{~kg}$ ha- 1 of $\mathrm{K}$ as potassium sulphate in two equal biweekly doses. Weed, pest, 
and disease control were done in a timely manner. Hand harvesting was performed about 60 days after sowing.

\subsection{Crop evapotranspiration measurements and irrigation water compensation}

Actual crop evapotranspiration under the different irrigation treatments was calculated using the soil water balance equation (Heerman, 1985):

$\mathrm{ET}=\mathrm{I}+\mathrm{P}+\mathrm{C}_{\mathrm{r}}+\mathrm{R}-\mathrm{D} \pm \Delta \mathrm{S}$

where ET represents seasonal crop evapotranspiration $(\mathrm{mm})$, I the amount of irrigation water applied $(\mathrm{mm}), \mathrm{P}$ is precipitation $(\mathrm{mm}), \mathrm{C}_{\mathrm{r}}$ is the capillary rise $(\mathrm{mm}), \mathrm{R}$ is the amount of runoff $(\mathrm{mm}), \mathrm{D}$ is the amount of drainage water $(\mathrm{mm})$.

In this study, both $\mathrm{P}$ and $\mathrm{C}_{\mathrm{r}}$ were considered to be zero because there was no precipitation during either growing season and no capillary rise from the groundwater occurred. Surface runoff was assumed to be negligible because the amount of irrigation water was controlled through the trickle irrigation. Whenever available water in the root zone $(0-20 \mathrm{~cm})$ and the total amount of water applied by irrigation were above the field capacity, it was assumed that excess water leaked into the deeper soil zones and was called deep percolation ( $\mathrm{D}=$ amount of available total water at $0-20$ $\mathrm{cm}$ soil depth before irrigation $(\mathrm{mm})+$ irrigation water applied $(\mathrm{mm})$ - soil water hold in field capacity (mm)) (Kanber et al 1993). Whereas $D_{S}$ was estimated from the respective soil water contents to a depth of $60 \mathrm{~cm}$ by using the soil water content value before harvesting to subtract the soil water content value before sowing.

Soil water content was monitored before irrigation every 15 days for $F_{1}$, $F_{2}$ and $F_{3}$ treatments, at soil depth intervals of $0-10$ and $10-20 \mathrm{~cm}$. Soil samples were taken at positions immediately under the emitters. Soil water content was determined by the gravimetric method (oven dry basis). The values were converted to a percentage volumetric basis by multiplying them by the bulk density of the soil of their layer. In addition, 
the contribution of the different treatments toward plant water consumption (Ertek et al., 2004) was determined according to

$\operatorname{Irc}=\left(\frac{\mathrm{I}}{\mathrm{ET}}\right) \times 100$

Where Irc is the irrigation water compensation for plant water

consumption (ET) (\%), I the amount of irrigation water applied.

\subsection{Water use efficiencies}

WUE $\left(\mathrm{kg} \mathrm{ha}^{-1} \mathrm{~mm}^{-1}\right.$ ), defined as the ratio of yield to seasonal water consumption per hectare, and irrigation water use efficiency (IWUE, kg $\mathrm{ha}^{-1} \mathrm{~mm}^{-1}$ ), as the ratio of grain yield to the seasonal amount of irrigation water applied per hectare, were calculated using Eqs. (6) and (7), respectively (Howell et al., 1990).

$\mathrm{WUE}=\left(\frac{\mathrm{Y}}{E T_{c}}\right)$

IWUE $=\left(\frac{\mathrm{Y}}{\mathrm{I}}\right)$

Where $\mathrm{Y}$ is the economical yield $\left(\mathrm{kg} \mathrm{ha}^{-1}\right)$, ET the seasonal crop evapotranspiration $(\mathrm{mm})$, and $\mathrm{I}$ is the amount of irrigation water applied $(\mathrm{mm})$.Relationships were derived from seasonal crop evapotranspiration and grain yield data was obtained from the experiment.

\subsection{Statistical analysis}

All measurements in this study were analyzed using an analysis of variance (ANOVA) appropriate for a randomized complete block design in factorial arrangement two factors irrigation frequency and water application rate. They were replicated among blocks. Mean square of the product between the irrigation frequency and water application rate was used as the error term to test the interaction between both factors. Mean separation of treatment effects used Duncan's protected least significant differences (LSD) test. Probability levels lower than 0.05 were categorized as significant. All analyses used the Mstat program.

\section{Results and discussions}

\subsection{Irrigation water and crop evapotranspiration $\left(\mathbf{E T}_{\mathbf{C}}\right)$}

Table (2) presents seasonal crop $\mathrm{ET}_{\mathrm{C}}$ and irrigation water compensation values (Irc) as estimated by Eqs. (5) and (6), respectively. In both seasons, indicating that the soil became drier at the end of the growing season. 
Seasonal irrigation water requirement of green bean for the recommended treatment was 271.6 and 233. $\mathrm{mm}$ for the experimental years, respectively. (Silim and Saxena 1993) reported seasonal irrigation water requirement for drip-irrigated green beans in Syria as $439 \mathrm{~mm}$; and (Borosic et al. 2000) determined water requirement of green beans as $400 \mathrm{~mm}$ in Zagreb. Since the rainfall received during the growing season was not significant, the crop water consumption practically depended only on the amount of the irrigation water supplied to the plots. In this study, the seasonal crop $\mathrm{ET}_{\mathrm{C}}$ during the crop growing period (i.e., after establishment of the crop) was found to be lower than the amount of irrigation water applied (I) in the $\mathrm{F}_{1} \mathrm{I}_{1}$ and $\mathrm{F}_{3} \mathrm{I}_{1}$ treatments

Table 5. Green bean evapotranspiration calculated using the water balance equation. $\mathrm{I}, \mathrm{ET}_{\mathrm{C}}$ and Irc indicate amount of irrigation water applied $(\mathrm{mm})$, change of soil water storage $(\mathrm{mm})$, crop evapotranspiration $(\mathrm{mm})$ and irrigation water compensation (\%), respectively.

\begin{tabular}{|c|c|c|c|c|c|}
\hline Year & Treatments & & $\begin{array}{c}\mathrm{I} \\
(\mathrm{mm})^{\mathrm{a}}\end{array}$ & $\begin{array}{c}\mathrm{ET}_{\mathrm{c}} \\
(\mathrm{mm})\end{array}$ & $\begin{array}{l}\text { Irc } \\
(\%)\end{array}$ \\
\hline \multirow[t]{9}{*}{2013} & \multirow[t]{3}{*}{$\mathrm{F}_{1}$ (once in 1 day) } & $1.00 \mathrm{ET}$ & 242.5 & 271.6 & 89.3 \\
\hline & & $0.80 \mathrm{ET}$ & 194 & 217.3 & 89.3 \\
\hline & & $0.60 \mathrm{ET}$ & 145.5 & 163.0 & 89.3 \\
\hline & \multirow[t]{3}{*}{$\mathrm{F}_{2}$ (once in 2 day) } & $1.00 \mathrm{ET}$ & 242.5 & 286.4 & 84.7 \\
\hline & & $0.80 \mathrm{ET}$ & 194 & 229.1 & 84.7 \\
\hline & & $0.60 \mathrm{ET}$ & 145.5 & 171.8 & 84.7 \\
\hline & \multirow[t]{3}{*}{$\mathrm{F}_{3}$ (once in 3 day) } & $1.00 \mathrm{ET}$ & 242.5 & 327 & 74.2 \\
\hline & & $0.80 \mathrm{ET}$ & 194 & 261.6 & 74.2 \\
\hline & & $0.60 \mathrm{ET}$ & 145.5 & 196.2 & 74.2 \\
\hline \multirow[t]{9}{*}{2014} & \multirow[t]{3}{*}{$\mathrm{F}_{1}$ (once in 1 day) } & 1.00ET & 209.3 & 233.5 & 89.6 \\
\hline & & $0.80 \mathrm{ET}$ & 167.4 & 186.8 & 89.6 \\
\hline & & $0.60 \mathrm{ET}$ & 125.5 & 140.2 & 89.6 \\
\hline & \multirow[t]{3}{*}{$\mathrm{F}_{2}$ (once in 2 day) } & $1.00 \mathrm{ET}$ & 209.3 & 240 & 87.2 \\
\hline & & $0.80 \mathrm{ET}$ & 167.4 & 192 & 87.2 \\
\hline & & $0.60 \mathrm{ET}$ & 125.5 & 144 & 87.2 \\
\hline & \multirow[t]{3}{*}{$\mathrm{F}_{3}$ (once in 3 day) } & $1.00 \mathrm{ET}$ & 209.3 & 302.7 & 69.0 \\
\hline & & $0.80 \mathrm{ET}$ & 167.4 & 242.2 & 69.0 \\
\hline & & $0.60 \mathrm{ET}$ & 125.5 & 181.6 & 69.0 \\
\hline
\end{tabular}

a: Amount of irrigation water applied was calculated by using Penman-Monteith equations 


\subsection{Yield components}

All yield components (the number of pods, the number of leaves and the area of leaves, and the yield per hectare were significantly affected by irrigation frequency and rate (Table 3 ). The maximum yield components and grain yield averaged across irrigation rate treatments were obtained at the two most frequent irrigation frequencies $\left(F_{1}\right.$ and $\left.F_{2}\right)$. Averaged over the two seasons, the irrigation frequency treatment $F_{3}$ resulted in decreases in ear weight per plant by 39.2 pods number per plant by 31.2 and $22.5 \%$, number of leaves 18.9 and $21.2 \%$ and yield per hectare of 48.1 and $22.6 \%$, respectively, when compared with the $F_{1}$ treatment (Table 3).

The combination of irrigation frequency and irrigation rate had a significant effect on both yield components and grain yield in both seasons (Table 3). The Duncan's protected LSD test of the various combinations for the effect on yield components and grain yield placed $F_{1} I_{2}$ and $F_{2} I_{1}$ in the first position; $F_{1} I_{1}, F_{3} I_{1}$ and $F_{2} I_{2}$ in the second position; $F_{3} I_{2}$ and $F_{1} I_{3}$ in the third position; $F_{2} I_{3}$ in the fourth position; $\mathrm{F}_{3} \mathrm{I}_{3}$ in the fifth position with similar results for all parameters in both seasons. (Boutraa and Sanders 2001) stated that water stress during the vegetative growth period and prior to fruit set had the greatest effects on limiting green bean yields.

\subsection{Water use efficiencies}

The highest WUE $22.3 \mathrm{~kg} \mathrm{~mm}^{-1}$ was obtained in $\mathrm{F}_{1} \mathrm{I}_{2}$ treatment in the first year and the minimum WUE was observed in $\mathrm{F}_{3} \mathrm{I}_{3}$ treatment in the second year. In general, WUE values decreased with decreasing number of frequency. IWUE values varied from a minimum of $13.2 \mathrm{~kg} \mathrm{~mm}^{-1}$ in $\mathrm{F}_{3} \mathrm{I}_{3}$ treatment to a maximum of $24.2 \mathrm{~kg} \mathrm{~mm}^{-1}$ in $\mathrm{F}_{1} \mathrm{I}_{2}$ treatment in the first year. Treatment was only 24.9 and $30.7 \%$ less than those at $F_{1}$ treatment, whereas the respective values for the $F_{2}$ and $F_{3}$ treatments showed significant decreases: IWUE, 37.5 and $45.9 \%$; WUE, 40.9 and $55.1 \%$ (for F2 andF3, respectively, in both cases). Averaged over all irrigation frequencies and seasons, $0.80 \mathrm{ET}_{\mathrm{C}}$ had comparable water use efficiencies as did $1.00 \mathrm{ET}_{\mathrm{C}}$, but $0.60 \mathrm{ET}_{\mathrm{C}}$ had IWUE and WUE values that were 41.1 and $34.7 \%$ lower than those of $1.00 \mathrm{ET}_{\mathrm{C}}$, respectively.

The interaction effect between irrigation frequency and rate on IWUE and WUE was also significant in both seasons (Table 3). 
Table 3. Effects of irrigation frequency, irrigation rate and their combination on grain yield, irrigation water use efficiency, $\mathrm{ET}_{\mathrm{C}}$, Irrigation water used and water use efficiency in 2013 and 2014.

\begin{tabular}{|c|c|c|c|c|c|c|c|c|}
\hline \multirow{2}{*}{$\begin{array}{l}\text { Irrigation } \\
\text { Frequency }\end{array}$} & \multicolumn{4}{|l|}{2013} & \multicolumn{4}{|l|}{2014} \\
\hline & $\begin{array}{c}1.00 \mathrm{ET}_{\mathrm{C}} \\
\left(\mathrm{I}_{1}\right)\end{array}$ & $\begin{array}{c}0.80 \mathrm{ET}_{\mathrm{C}} \\
\left(\mathrm{I}_{2}\right)\end{array}$ & $\begin{array}{c}0.60 \mathrm{ET}_{\mathrm{C}} \\
\left(\mathrm{I}_{3}\right)\end{array}$ & Mean & $\begin{array}{c}1.00 \mathrm{ET}_{\mathrm{C}} \\
\left(\mathrm{I}_{1}\right)\end{array}$ & $\begin{array}{c}0.80 \mathrm{ET}_{\mathrm{C}} \\
\left(\mathrm{I}_{2}\right)\end{array}$ & $\begin{array}{c}0.60 \mathrm{ET}_{\mathrm{C}} \\
\left(\mathrm{I}_{3}\right)\end{array}$ & Mean \\
\hline \multicolumn{9}{|l|}{ Grain yield $\left(\mathrm{kg} \mathrm{ha}^{-1}\right)$} \\
\hline $\mathrm{F}_{1}$ (once in 1 day) & $10320 \mathrm{ab}$ & $11430 \mathrm{a}$ & 6613de & $9453 a$ & $10290 \mathrm{~b}$ & $11930 \mathrm{a}$ & $6516 \mathrm{e}$ & $9578 \mathrm{a}$ \\
\hline $\mathrm{F}_{2}$ (once in 2 days) & $10450 \mathrm{ab}$ & $8946 b c$ & $5446 \mathrm{e}$ & $8280 \mathrm{ab}$ & 10460 & $8706 \mathrm{c}$ & $5510 \mathrm{f}$ & $8224 a b$ \\
\hline $\mathrm{F}_{3}$ (once in 3 days) & $10240 \mathrm{ab}$ & $7820 \mathrm{~cd}$ & $4757 \mathrm{e}$ & $7606 b$ & $10280 b$ & $7417 d$ & $4561 \mathrm{~g}$ & $7418 b$ \\
\hline Mean & $10340 \mathrm{a}$ & $9398 b$ & $5605 c$ & & $10340 \mathrm{a}$ & $9352 b$ & $5529 \mathrm{c}$ & \\
\hline $\operatorname{LSD}(0.05)$ & F 1364 & ET 283.4 & F×ET 1817 & & F 1477 & ET 433.7 & $\mathrm{~F} \times \mathrm{ET} 595.3$ & \\
\hline \multicolumn{9}{|l|}{ IWUE $\left(\mathrm{kg} \mathrm{mm}^{-1}\right)$} \\
\hline $\mathrm{F}_{1}$ (once in 1 day) & $42.35 \mathrm{c}$ & $59.20 \mathrm{a}$ & $45.75 b$ & $49.10 \mathrm{a}$ & $49.90 \mathrm{~b}$ & $72.05 \mathrm{a}$ & $51.45 b$ & $75.80 \mathrm{a}$ \\
\hline $\mathrm{F}_{2}$ (once in 2 days) & $42.60 \mathrm{c}$ & $45.60 \mathrm{~b}$ & $37.25 \mathrm{e}$ & $41.82 \mathrm{ab}$ & $50.45 b$ & $51.20 \mathrm{~b}$ & $43.50 \mathrm{c}$ & $48.38 b$ \\
\hline $\mathrm{F}_{3}$ (once in 3 days) & $41.5 \mathrm{~cd}$ & $39.85 \mathrm{~d}$ & $32.5 \mathrm{f}$ & $37.97 b$ & $50.10 \mathrm{~b}$ & $43.60 \mathrm{c}$ & $36.00 \mathrm{~d}$ & $43.23 b$ \\
\hline Mean & $42.17 b$ & $48.22 \mathrm{a}$ & $38.5 \mathrm{c}$ & & $50.15 b$ & $55.62 \mathrm{a}$ & $43.65 \mathrm{c}$ & \\
\hline LSD $(0.05)$ & F 7.715 & ET 1.173 & F×ET 2.033 & & F 8.256 & ET 0.958 & F×ET 1.66 & \\
\hline \multicolumn{9}{|l|}{ WUE $\left(\mathrm{kg} \mathrm{mm}^{-1}\right)$} \\
\hline $\mathrm{F}_{1}$ (once in 1 day) & $38.40 \mathrm{~b}$ & $52.65 \mathrm{a}$ & $40.35 b$ & $43.80 \mathrm{a}$ & $44.90 \mathrm{~b}$ & $64.20 \mathrm{a}$ & $45.80 \mathrm{~b}$ & $51.63 \mathrm{a}$ \\
\hline $\mathrm{F}_{2}$ (once in 2 days) & $36.65 b c$ & $38.70 \mathrm{~b}$ & $36.05 b c$ & $37.13 b$ & $44.25 b$ & $44.65 b$ & $38.25 \mathrm{c}$ & $42.38 b$ \\
\hline $\mathrm{F}_{3}$ (once in 3 days) & $31.0 \mathrm{~cd}$ & $29.95 d$ & $24.05 \mathrm{e}$ & $28.33 \mathrm{c}$ & $34.45 \mathrm{~d}$ & $30.55 \mathrm{e}$ & $25.15 f$ & $30.05 c$ \\
\hline Mean & $35.35 \mathrm{~b}$ & $40.43 a$ & $33.48 b$ & & $41.20 \mathrm{~b}$ & $46.47 a$ & $36.40 \mathrm{c}$ & \\
\hline $\operatorname{LSD}(0.05)$ & F 1.151 & ET 3.343 & F×ET 5.790 & & F 6.586 & ET 0.932 & F×ET 1.62 & \\
\hline
\end{tabular}

Means followed by the same letter are not significantly different from one another based on Duncan's protected LSD test at $\mathrm{P} \leq 0.05$. 
An important finding of this study was the strong response of both grain yield and yield components to the combination of irrigation frequency and amount. It is interesting to note that the values of both grain yield and yield components obtained for $F_{1} I_{2}$ were comparable with those of $F_{2} I_{1}$, and that both were higher than those obtained for $F_{1} I_{1}$. Crucially, the $F_{1} I_{3}$ treatment produced grain yield and yield components values similar to those obtained for the $\mathrm{F}_{2} \mathrm{I}_{3}$ and $\mathrm{F}_{3} \mathrm{I}_{2}$ treatments (Table 3). The was nonsignificant difference between the $\mathrm{F}_{3} \mathrm{I}_{1}$ and $\mathrm{F}_{1} \mathrm{I}_{3}$ treatments for IWUE and $\mathrm{ET}_{\mathrm{c}}$ (Table 3),despite the amount of water applied in the former case being 31.0\% higher in 2013 and 30.4\% in 2014 (Table 3), this may be explained by the application of water at high volume and low frequency in the $\mathrm{F}_{3} \mathrm{I}_{1}$ treatment exceeding the soil-water storage capacity, leading to excessive water percolation under the effective root zone. Therefore, frequent low rates of irrigation (e.g., $F_{1} I_{3}$ ) were more effective for increasing irrigation efficiencies than were infrequent high irrigation rates (e.g., $\left.\mathrm{F}_{3} \mathrm{I}_{1}\right)$ (Table 3).

\subsection{Yield-seasonal crop evapotranspiration relationship}

The best fit for the relationship between grain yield and seasonal crop ET was power and positive for each year: $2013, \mathrm{Y}=49.528 \mathrm{ET}^{0.9431}\left(\mathrm{R}^{2}=\right.$ 0.4899); 2014, $\mathrm{Y}=121.83 \mathrm{ET}{ }^{0.7965}\left(\mathrm{R}^{2}=0.3618\right)$ (Fig. 2). The power regression coefficients, which represent the increase in grain yield for each unit increase in seasonal crop ET, were $36.71 \mathrm{~kg} . \mathrm{mm}^{-1}$ in 2013 and $41.48 \mathrm{kgmm}^{-1}$ in 2014. The intercepts of the two regression lines were also highly similar. From the equations reported in Fig.2, the basal seasonal crop ET necessary to start grain yield production was determined to be 271.6 and $233.5 \mathrm{~mm}$ in 2013 and 2014 , respectively $(252.5 \mathrm{~mm}$ on average).

First, the shorter irrigation durations for higher irrigation frequencies in combination with high irrigation rates (i.e., $\mathrm{F}_{1} \mathrm{I}_{1}$ ) may mean that the amount of water extracted by the roots was not commensurate with the amount of water applied, resulting in more water moving below the root zone. Second, in the case of low irrigation frequencies in combination with high irrigation rates (i.e., $F_{3} I_{1}$ ), the amount of water applied at each irrigation event was (excessively) higher than the water storage capacity of the sandy soil, thereby like increasing the amount of water that could 
move below the root zone. In both cases, the amount of water that percolated under the root zone was not depleted by the roots.
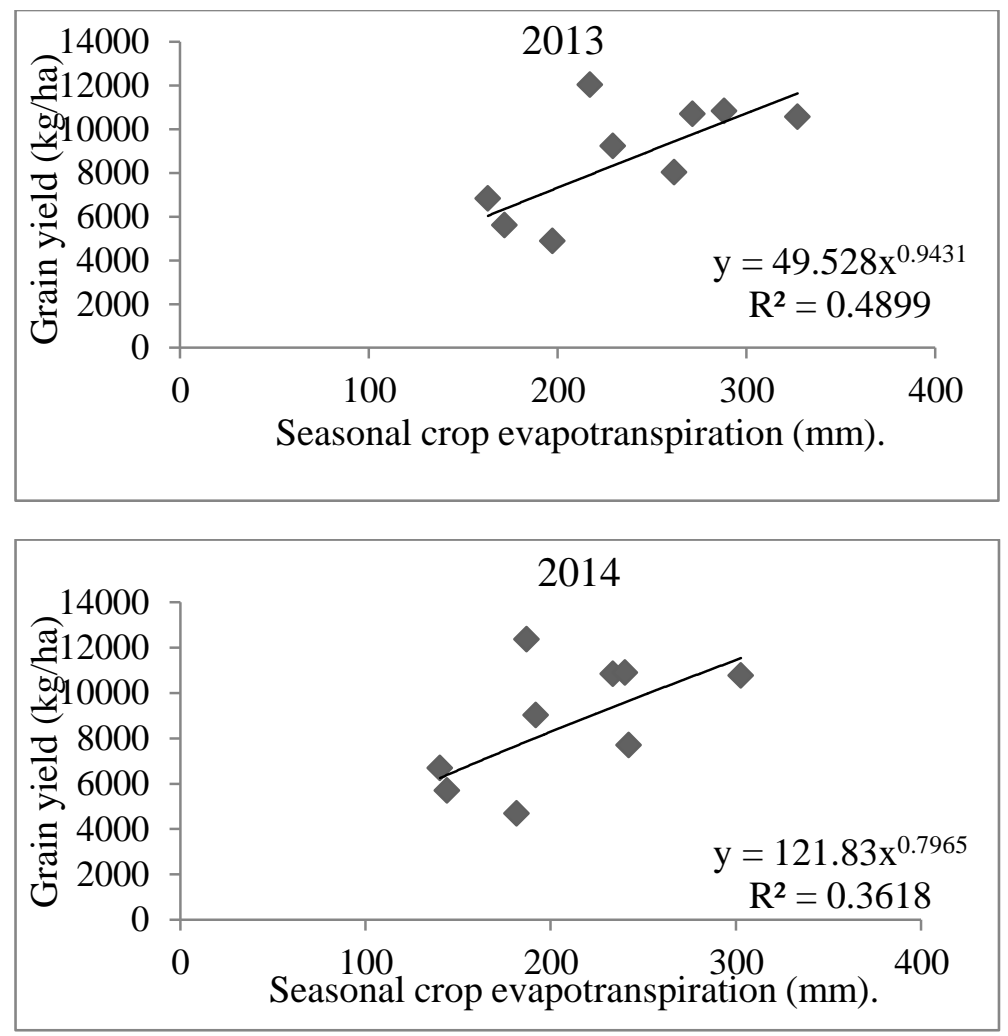

Fig. 2. Relationship between seasonal crop evapotranspiration $\left(\mathrm{ET}_{\mathrm{C}}\right)$ and grain yield under the two growing seasons.

\section{CONCLUSIONS}

- In this study, our results demonstrated that the deficit irrigation had significant effect on yields of field grown green bean under the Mediterranean climatic conditions in Egypt.

- The maximum yield of $11430 \mathrm{~kg} \mathrm{ha}^{-1}$ was obtained from $\mathrm{F}_{1} \mathrm{I}_{2}$ treatment in 2013 and $11930 \mathrm{~kg} \mathrm{ha}^{-1}$ in 2014. Moreover, $\mathrm{F}_{1} \mathrm{I}_{2}$ treatment resulted in better quality than as compared to other treatments.

- The results indicated that WUE and IWUE values decreased with the decreasing frequency irrigation, it is recommended to frequency irrigate $\mathrm{F}_{1}$ (once in 1 day) with irrigation rate of $0.80 \mathrm{ET}\left(\mathrm{I}_{2}\right)$. 
- In conclusion, $F_{1} I_{2}$ treatment is recommended for trickle-irrigated green bean grown under field conditions in order to save water by giving the media time to moisten from the first pulse of water thereby allowing it to absorb subsequent irrigation.

- We would be able to reduce the quantities of water apply needed to achieve optimal production. Considering the IWUE and WUE, $\mathrm{F}_{1} \mathrm{I}_{2}$ irrigation regime can be recommended in case of water shortage.

\section{REFERENCES}

Allen, R.G., Pereira, L.S., Raes, D., Smith, M. 1998. Crop evapotranspiration: guide lines for computing crop water requirements. FAO Irrigation and Drain. Pp. 56. UNFAO, Rome.

Alvino, A., Tedeschi, P., Zerbi, G., 1988. Growth, flowering, setting and yield of kidney bean (Phaseolus vulgaris L.) as influenced by water regime, P fertilization and bnoa treatment. Acta Hort. 228, 219-226.

ASAE. 1996a. Field Evaluation of Micro Irrigation Systems. EP405.1. ASAE Standards. Amer. Soc. Agric. Engr., St. Joseph, MI, pp. 756-759.

ASAE. 1996b. Design and Installation of Micro Irrigation Systems. EP409. ASAE Standards. Amer. Soc. Agric. Engr., St. Joseph, MI, pp. 792-797.

Assouline, S., 2002. The effects of micro drip and conventional drip irrigation on

Barros, L.C.G., Hanks, R.J., 1993. Evapotranspiration and yield of beans as affected by mulch and irrigation. Agron. J. 85, 692-697.

Bergez, J.E., Deumier, J.M., Lacroix, B., Leroy, P., Wallach, D. 2002. Improving irrigation schedules by using a biophysical and a decisional model. Eur. J. Agron. 16, 123-135.

Borosic, J., Romic, D., Dolanjski, D., 2000. Growth and yield components of dwarf French bean grown under irrigation conditions. Acta Hort. 533, 451-459. 
Boutraa, T., Sanders, F.E., 2001. Influence of water stress on grain yield and vegetative growth of two cultivars of bean (Phaseolus vulgaris L.). J. Agron. Crop Sci. 187, 251-257.

C,ag lar, G., 1998.In: Kahramanmaras kos, ullarında ikinci u“ rün olarak yes, il fasulye yetis, tiricilig ine uygun yer ve sirık c,es, itlerin belirlenmesi u“ zerine bir aras, tırma. II. Sebze Tarımı Sempozyumu. Gaziosmanpas, a U“' niv. Zir. Fak, Tokat, 28-30 Eylu“ 1, (in Turkish), pp. s: 199-s:204.

Chen, C., Payne, W.A., Smiley, R.W., Stoltz, M.A., 2003. Yield and water-use efficiency of eight wheat cultivars planted on seven dates in northeastern Oregon. Agron J. 95, 836-843.

Costa, J. M., Ortũno, M. F., Chaves, M. M. 2007. Deficit irrigation as a strategy to save water: physiology and potential application to horticulture. J. Integr. Plant Biol. 49, 1421-1434.

Doorenbos, J., Kassam, A.H., 1979. Yield response to water. FAO Irrigation and Drainage Paper 33. UN-FAO, Rome, Italy.

El-Hendawy, S.E., Abd El-Lattief, E.A., Ahmed, A.S., Schmidhalter, U. 2008. Irrigation rate and plant density effects on yield and water use efficiency of drip-irrigated corn. Agric. Water Manage. 95, 836844.

El-Hendawy, S.E., Hokam, E.M., Schmidhalter, U., 2008. Drip irrigation frequency: the effects and their interaction with nitrogen fertilization on sandy soil water distribution, maize yield and water use efficiency under Egyptian conditions. J. Agron. Crop Sci. 194, 180-192.

English, M. J. 1990. Deficit irrigation: an analytical framework. J. ASCE (IR). 116: 399-412.

English, M., Raja, S. N. 1996.Perspective on deficit irrigation. Agric. Water Management 32, 1-14. 
Eric, S., David, S., Robert, H. 2004. To pulse or not to pulse trickle irrigation that is the question UF/IFAS - Horticultural Sciences Department. Florida, USA NFREC-SV-Vegetarian (04-05).

Ertek, A., Ss ensoy, S., Ku“ c,u“ kyumuk, C., Gedik, I., 2004. Irrigation frequency and

Fereres, E., Soriano, M.A. 2007. Deficit irrigation for reducing agricultural water use J. Exp. Bot. 58, 147-159.

Heerman, D.F. 1985. ET in irrigation management. In: Proceedings of the National Conference on Advances in Evapotranspiration. Trans. ASAE. Pp. 323-334.

Hillel, D. 1972. The relationship between field water balance and water use efficiency. In: Hillel D(Ed) Optimizing the Soil Physical Environment Toward Greater Crop Yields (pp. 79-100) Academic Press, New York.

Howell, T.A., Cuenca, R.H., Solomon, K.H., 1990. Crop yield response. In: Hoffman, G.J., Howell, T.A., Solomon, K.H. (Eds.), Management of Farm Irrigation Systems. ASAE Monograph No. 9, 2950 Niles Road, St. Joseph, MI, pp. 93-122.

Istanbulluoglu, A. 2009. Effects of irrigation regimes on yield and water productivity of safflower (Carthamustinctorius L.) under Mediterranean climatic conditions. Agric. Water Manage. 96, 1792-1798.

Jackson, M. L. 1973. Soil chemical analysis. Prentice hall, Inc. N.Y.

Jones, H., 2004. Irrigation scheduling advantages and pitfalls of plant based methods.

Kanber, R., Yazar, A., O“ nder, S., Ko“ ksal, H. 1993. Irrigation response of Pistachio. Irrig. Sci. 14, 1-14.

Kirda, C. 2002. Deficit irrigation scheduling based on plant growth stages showing water stress tolerance. Deficit irrigation practices. In: FAO Corp. Doc. Rep. 22, Rome, pp. 3-10. 
Kirnak, H., Demirtas, M.N., 2006. Effects of different irrigation regimes and mulches on yield and macro nutrition levels of drip-irrigated cucumber under open field conditions. J. Plant Nutr. 29, 16751690.

Kirnak, H., Gencoglan, C., Degirmenci, V., 2003. Effect of deficit irrigation on yield and growth of second crop corn in Harran plain conditions. Atatu“" rk Univ. J. Fac. Agric. 34 (2), 117-123.

Kriedemann, P.E., Goodwin, I. 2003. Regulated Deficit Irrigation and Partial Root-zone Drying. An Overview of Principles and Applications. Irrigation Insights no. 3.Land and Water, Australia.

Merriam, J. L. 1965. A management control concept for detonating the economical frequency of irrigation. ASAE Annual Meeting, Paper No. 65-206, St Joseph, Michigan.

Moon, D., Gulik, W.V., 1996. Irrigation scheduling using GIS. In: Proceedings of the International Conference on Evapotranspiration and Irrigation Scheduling, Am. Soc. Agric. Eng., San Antonio, TX, USA, November 3-6, pp. 644-649.

Muirhead, W.A., 1978. Snap beans. Farmers Newsletter. 144, 24-25.

Musick, J.T., Jones, O.R., Stewart, B.A., Dusek, D.A., 1994. Water-yield relationships for irrigated and dryland wheat in the U.S. Southern Plains. Agron. J. 86, 980- 986.

Oweis, T., Hachum, A. 2001. Reducing peak supplemental irrigation demand by tending sowing dates. Agric. Water Manage. 50, 109124.

Patanè, C., Cosentino, S.L. 2010. Effects of soil water deficit on yield and quality of processing tomato under a Mediterranean climate. Agric. Water Manage. 97, 131-138.

Payero, J.O., Melvin, S.R., Irmak, S., Tarkalson, D., 2006. Yield response of corn to deficit irrigation in a semiarid climate. Agric. Water Manage. 84, 101-112. 
Phene, C.J., Sanders, D.C. 1976. High-frequency trickle irrigation and row spacing effects on yield and quality of potatoes. Agron. J. 68, 602-607.

Stanghellini, C., Kempkes, F.L.K., Knies, P. 2003. Enhancing environmental quality in agricultural systems. Acta Hortic. 609, 277-283.

\section{الملخص العربيى}

تأثير ادارة الرى بالتثقيط على محصول الفاصوليا الخضراء فى الار اضى الطميية الطينية

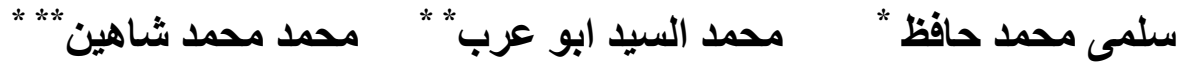

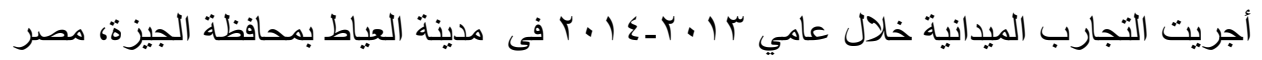

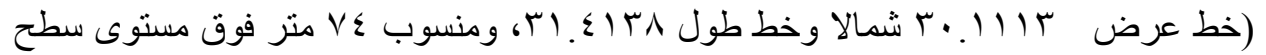
(البحر). وكانت معاملات الرى الثحيح (2.60ET

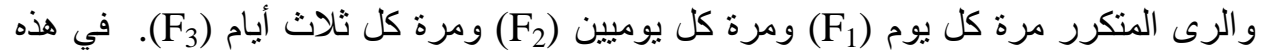

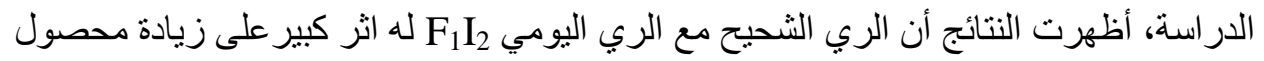

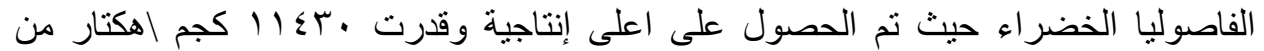

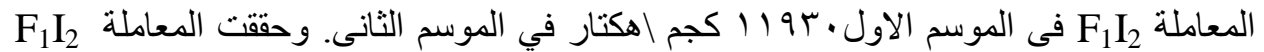

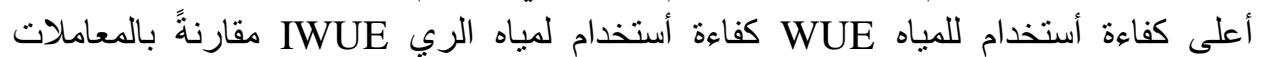

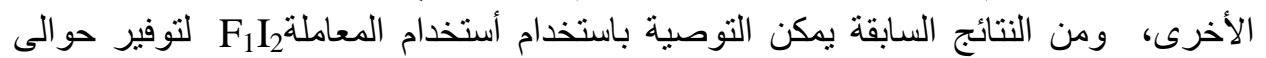
• • . من خلالها سوف نكون قادرين على تقليل كميات المياه اللازمة لتحقيق اقصى الزية التاجية.

*طالبة ماجستير قسم الهندسة الزراعية ـ كلية الزراعة ـ جامعة القاهرة.

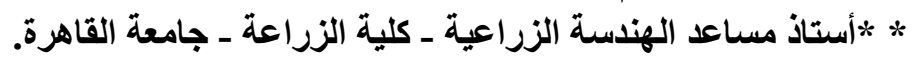
*** ** * * *اذ مساعد الخضر ـ كلية الزراعة - جامعة القاهرة. 